\title{
Influence of Some Mineral Ions on Lipid Peroxidation in Vitro
}

\author{
Ďurfinová M. ${ }^{1}$, Brechtlová M. ${ }^{1}$, Kuračka L'. ${ }^{1}$, Zálešáková J. ${ }^{2}$, Čelko J. ${ }^{2}$, \\ Líška B.1 \\ ${ }^{1}$ Department of Medical Chemistry, Biochemistry and Clinical Biochemistry, Faculty \\ of Medicine, Comenius University, Bratislava, Slovak Republic; \\ 2Department of Physiotherapy and Balneology, Slovak Medical University, Bratislava, \\ Slovak Republic
}

Received December 20, 2011; Accepted June 25, 2012.

Key words: Aluminium - Silicon - Natrium sulphide - Lipid peroxidation - Brain

Abstract: Recently, a growing interest has been recorded in mineral content of mammalian diet, which might impair their development. Focused on the topic, we studied the effect of $\mathrm{Al}^{3+}, \mathrm{Si}^{4+}, \mathrm{Sr}^{2+}$ and $\mathrm{Na}_{2} \mathrm{~S}$ on the intensity of malondialdehyde (MDA) production in vitro. MDA, as one of oxidative stress markers, was determined in rat brain homogenates in the conditions of lipid peroxidation (LP) activated by iron ions and ascorbate. Our results showed a significant increase in lipid peroxidation after addition of aluminium ions. We assume a probable impact of $\mathrm{Al}^{3+}$ on active or regulatory centres of antioxidant enzymes, resulting in the reduction of their antioxidant functions. The addition to $\mathrm{Si}^{4+}$ or $\mathrm{Na}_{2} \mathrm{~S}$ to samples with $\mathrm{Al}^{3+}$ significantly decreased $\mathrm{Fe}^{2+}$-activated LP. We can explain the influence of $\mathrm{Na}_{2} \mathrm{~S}$ by the formation of insoluble complexes with iron. Similarly, the effect of $\mathrm{Si}^{4+}$ can be related to the production of aluminium-silicon complexes. In our view, an optimal ratio of aluminium and silicon ions (or aluminium ions and $\mathrm{Na}_{2} \mathrm{~S}$ ) in the diet might have beneficial effects on brain functions.

This study was supported by the contract No. II/86/05 between Slovak Health Spa, a.s., Trenčianske Teplice and Faculty of Medicine, Comenius University, Bratislava.

Mailing Address: RNDr. Monika Ďurfinová, PhD., Department of Medical Chemistry, Biochemistry and Clinical Biochemistry, Faculty of Medicine, Comenius University, Sasinkova 2, 81108 Bratislava, Slovak Republic; Phone: +421 259357 575; Fax: +421 259357 557; e-mail: monika.durfinova@fmed.uniba.sk 


\section{Introduction}

In recent years, the interest in aluminium $(\mathrm{Al})$ exposure through the diet and environment has increased. There are several studies which found relation between aluminium and Alzheimer's disease (AD) (Carlise and Curran, 1987; Exlay, 1999; Bocca et al., 2005). Aluminium can damage neuronal cells by altering physiological properties of their membranes, interfering with the function of voltage-activated ion channels or altering the secretion of transmitters (Donald et al., 1989). Several factors seem to influence the neurotoxic effects of aluminium. These include the integrity of the blood-brain barrier, the ability of the brain to get rid of a certain substance and the developmental stage of the brain (Nehru and Anand, 2005). Aluminium exposure inhibits the prenatal and postnatal development of the brain in humans and experimental animals. The brain's ability to get rid of a certain substance probably depends on several factors such as: metal binding proteins, scavenging molecules (e.g. glutathione), the status of the redox enzyme system (superoxide dismutase, catalase, glutathione peroxidase), as well as their interaction with other micronutrient elements. A disruption of the blood-brain barrier can lead to an increased penetration and accumulation of aluminium in brain cells.

It has been published that silicon $(\mathrm{Si})$ is associated with calcium and phosphorus levels in the brain and therefore the lack of it, especially at low calcium content in the diet, has an effect similar to the process of AD (Zálešáková and Čársky, 2005). It is assumed that silicon may be a protective factor in brain cells, especially during the increased supply of aluminium (Carlise and Curran, 1987).

Results from some epidemiological studies suggest that the neurotoxic effects of $\mathrm{Al}^{3+}$ from a diet depend also on other food constituents. It seems that silicon presented in drinkable water may protect against the risk of AD development (Forbes and Agwani, 1994).

In our present study, effects of some minerals (aluminium, silicon, strontium) and sodium sulphide on the status of lipid peroxidation were measured using in vitro model. The nonenzymatic lipid peroxidation reaction is known to be catalyzed by a transition metal ion and a reductant agent, such as ascorbic acid, and requires oxygen as well as polyunsaturated fatty acids. Thus, the brain and nervous tissues are especially sensitive to oxidative damage for their high consumption of oxygen and their high content of membrane lipids containing polyunsaturated fatty acids (Halliwell and Gutteridge, 1999).

The aim of our study was to assess and try to explain the impact of excessive amount of minerals and their combinations on lipid peroxidation (LP) processes by measuring of malondialdehyde (MDA) level in the brain tissue. Such model experiments represent continuation of our previous study, which analysed the impact of the mineral water (from a Slovak spa, Trenčianske Teplice) on lipid peroxidation processes in the rat brain homogenates (Ďurfinová et al., 2010). Preparation of our recent experiments allowed us to investigate the influence of 
ion combinations found in mineral water on LP also under pathological conditions (activation of polyunsaturated fatty acids oxidation by LP activators and higher temperature).

\section{Material and Methods}

Seventeen male healthy Wistar rats (adult weighing 300-400 g) were provided by the Medical Faculty (Brno, CZ-62760158). All animals were fed on the commercial rat diet and water ad libitum. After decapitation, the brain was rapidly removed and $1 \mathrm{~min}$ homogenized at $0{ }^{\circ} \mathrm{C}$ in $8.3 \mathrm{mmol} / \mathrm{l}$ Tris- $\mathrm{HCl}$. Homogenates were not pooled before analysis. All experiments were performed in accordance with the "Guide for the Care and Use of Laboratory Animals" published by the US National Institute of Health (NIH Publication No. 85-23, revised 1985), as well as with the guidelines formulated by the European Community for the use of experimental animals (L358-86/609/EEC).

Products of lipid peroxidation were determined in $2 \%(\mathrm{w} / \mathrm{v})$ brain homogenates (Ohkawa et al., 1979). The homogenates were used for analysis immediately (no incubation) and after 30 min incubation at $37{ }^{\circ} \mathrm{C}$ without (no effector) and with the activator of lipid peroxidation. As the activators, $\mathrm{FeSO}_{4}(5 \mu \mathrm{mol} / \mathrm{l})$ or mixture of ascorbate $(125 \mu \mathrm{mol} / \mathrm{l})$ and $\mathrm{FeSO}_{4}(5 \mu \mathrm{mol} / \mathrm{l})$, were used.

The reaction was carried out by mixing of $0.3 \mathrm{ml}$ homogenate in Tris- $\mathrm{HCl}$ $(\mathrm{pH} 7.25)$ and $0.1 \mathrm{ml}$ of the lipid peroxidation activator. For control samples, $0.1 \mathrm{ml}$ of deionized water was used instead of the lipid peroxidation activator. These activators were combined without (control) and with some selected ions contained in mineral water 1:1 (v/v). Concentration of minerals was the same as in drill source: $0.54 \mathrm{mmol} / \mathrm{l} \mathrm{Na} \mathrm{SiO}_{3}$ (Si); $90 \mu \mathrm{mol} / \mathrm{l} \mathrm{Na} \mathrm{N}_{2} \mathrm{~S} \cdot 9 \mathrm{H}_{2} \mathrm{O}$ (sulphide); $3.5 \mu \mathrm{mol} / \mathrm{l}$ $\mathrm{AlCl}_{3} \cdot 6 \mathrm{H}_{2} \mathrm{O}(\mathrm{Al})$ and $51.1 \mu \mathrm{mol} / \mathrm{l} \mathrm{Sr}\left(\mathrm{NO}_{3}\right)_{2}(\mathrm{Sr}) .0 .2 \mathrm{~mol} / \mathrm{l}$ phosphoric acid and $0.6 \%$ thiobarbituric acid (TBA) (w/v) were added immediately or after incubation procedure. The reaction mixture was heated at $100{ }^{\circ} \mathrm{C}$ for $30 \mathrm{~min}$ and then cooled in iced water. The produced complexes were extracted into $n$-butanol and centrifuged at $1000 \times \mathrm{g}$ for $10 \mathrm{~min}$.

The complexes of malondialdehyde (MDA) with TBA were determined by modified HPLC method (Ďurfinová et al., 2010). The used HPLC system was Lachrom HITACHI from Merck (Germany) with UV detector (L-7400) at $532 \mathrm{~nm}$. As a mobile phase, potassium phosphate buffer $(0.1 \mathrm{~mol} / \mathrm{l}, \mathrm{pH} 6.3)$ and methanol $1: 1(\mathrm{v} / \mathrm{v})$ with the flow rate of $0.9 \mathrm{ml} / \mathrm{min}$ was used. Lichrospher $100 \mathrm{RP}-18$ analytical column (5 $\mu \mathrm{m}$ particle size) from Merck (Germany) was employed for the separation of the MDA-TBA adducts. The retention time MDA-TBA was $3.26 \mathrm{~min}$. Results were evaluated by means of the evaluating program Chromatography Station for Windows (CSW version 1.7) from DATA Apex Ltd. (Czech Republic).

Results were expressed in nmol of MDA per $\mathrm{mg}$ of proteins. Proteins were determined by the method of Lowry et al. (1951), using bovine albumin as a 
standard. The data has been expressed as mean \pm SEM 10-17 separate experiments in triplicates. Statistical analysis was performed using Student's t-test. The level of significance was $p<0.05$.

\section{Results}

In our previous work, we found an inhibitory effect of mineral water (from a Slovak spa, Trenčianske Teplice) on lipid peroxidation processes, activated by iron ions without/with ascorbate, in rat brain homogenates (Ďurfinová et al., 2010). In our opinion, any component or a combination of more components of the mineral water might act as a chelator of iron ions.

In our present study, we monitored the impact of silicon $\left(\mathrm{Si}^{4+}\right)$, aluminium $\left(\mathrm{Al}^{3+}\right)$, strontium $\left(\mathrm{Sr}^{2+}\right)$ ions and $\mathrm{Na}_{2} \mathrm{~S}$ on LP processes in rat brain homogenates. The content of MDA-TBA was not affected by these mineral ions compared to samples without them (Table 1, no incubation). In control group, iron ions increased LP approximately 6-times, comparing to samples incubated with no effector. Moreover, iron in combination with ascorbate, during the same incubation, resulted in the increase of LP products approximately 14-times versus samples with no effector.

\section{Table 1 - Effect of some minerals on MDA-TBA level in rat brain homogenates}

\begin{tabular}{|c|c|c|c|c|c|c|}
\hline & & Control & $\mathrm{Si}^{4+}$ & $\mathrm{Sr}^{2+}$ & $\mathrm{Al}^{3+}$ & $\mathrm{Na}_{2} \mathrm{~S}$ \\
\hline No incubat & ion & $0.95 \pm 0.09$ & $0.90 \pm 0.14$ & $0.68 \pm 0.09$ & $0.72 \pm 0.12$ & $0.71 \pm 0.09$ \\
\hline \multirow{3}{*}{$\begin{array}{l}\text { Incubation } \\
30 \mathrm{~min} / \\
37^{\circ} \mathrm{C} \\
\text { with: }\end{array}$} & $\begin{array}{l}\text { No } \\
\text { effector }\end{array}$ & $1.15 \pm 0.20$ & $0.95 \pm 0.05$ & $0.92 \pm 0.03$ & $0.9 \pm 0.04$ & $0.98 \pm 0.06$ \\
\hline & $\mathrm{Fe}^{2+}$ & $5.90 \pm 0.59 *$ & $3.90 \pm 0.46 * *$ & $6.30 \pm 0.49$ & $8.6 \pm 0.36 * * *$ & $1.9 \pm 0.20^{* *}$ \\
\hline & $\begin{array}{l}\mathrm{Fe}^{2+}+ \\
\text { ascorbate }\end{array}$ & $13.48 \pm 0.80^{*}$ & $10.15 \pm 0.9$ & $14.3 \pm 0.55$ & $14.7 \pm 0.7$ & $10.2 \pm 0.48$ \\
\hline
\end{tabular}

\footnotetext{
Values are expressed in nmol MDA/mg proteins, as means \pm SEM of 17 determinations

Control - without addition of mineral ions; $\mathrm{Si}^{4+}-0.54 \mathrm{mmol} / \mathrm{l} \mathrm{Na} \mathrm{SiO}_{3} ; \mathrm{Sr}^{2+}-51.1 \mu \mathrm{mol} / \mathrm{I} \mathrm{Sr}\left(\mathrm{NO}_{3}\right)_{2}$;

$\mathrm{Al}^{3+}-3.5 \mu \mathrm{mol} / / \mathrm{AlCl}_{3} \cdot 6 \mathrm{H}_{2} \mathrm{O} ; \mathrm{Na}_{2} \mathrm{~S}-90 \mu \mathrm{mol} / \mathrm{l} \mathrm{Na} \mathrm{N}_{2} \mathrm{~S} \cdot 9 \mathrm{H}_{2} \mathrm{O}$

*increase of LP intensity vs. samples with no effector $(P<0.001)$

**, ***significant changes of LP intensity after addition of minerals vs. samples without minerals (control), all in the presence of $\mathrm{Fe}^{2+}(p<0.001)$
}

The monitored mineral ions added to incubated samples significantly influenced only the intensity of MDA production in samples with iron ions (Table 1, control, $\mathrm{Fe}^{2+}$ ). A significant increase in LP intensity was measured in the presence of aluminium ions (about $50 \%$ ) versus samples with $\mathrm{Fe}^{2+}$ alone. On the other hand, a significant decrease in LP processes in the presence of $\mathrm{Na}_{2} \mathrm{~S}$ (about 65\%) and $\mathrm{Si}^{4+}$ (about 34\%) versus samples with $\mathrm{Fe}^{2+}$ alone was observed. Changes of LP intensity in the presence of strontium ions were not significant. 
Furthermore, the effect of mineral combinations on MDA production, activated by iron, was studied. We prepared mixtures: $\mathrm{Si}^{4+}+\mathrm{Na}_{2} \mathrm{~S}, \mathrm{Al}^{3+}+\mathrm{Si}^{4+}$ and $\mathrm{Al}^{3+}$ $+\mathrm{Na}_{2} \mathrm{~S}(1: 1, \mathrm{v} / \mathrm{v})$. The intensity of LP was monitored after 30-minute sample incubation at $37{ }^{\circ} \mathrm{C}$. A decrease in LP production (about 34\%) was observed in the presence of $\mathrm{Si}^{4+}+\mathrm{Na}_{2} \mathrm{~S}$, versus samples without these minerals (Table 2).

The addition of $\mathrm{Al}^{3+}$ to samples containing iron resulted in activation of LP processes (about $46 \%$ versus samples with iron alone). However, if $\mathrm{Si}^{4+}$ or $\mathrm{Na}_{2} \mathrm{~S}$ were present in the mixture with $\mathrm{Al}^{3+}$, the intensity of $\mathrm{LP}$ was significantly decreased in comparison to samples with aluminium in the presence of iron (Table 2).

Table 2 - Effect of mineral combination on iron activated lipid
peroxidation (LP) in rat brain homogenates

\begin{tabular}{lcc}
\hline \multicolumn{1}{c}{ Addition of $\mathrm{Fe}^{2+}$} & $5.9 \pm 0.60$ & $100 \%$ \\
\hline $\mathrm{Fe}^{2+}+\mathrm{Si}^{4+}+\mathrm{Na}_{2} \mathrm{~S}$ & $3.92 \pm 0.62^{*}$ & $-34 \% *$ \\
\hline $\mathrm{Fe}^{2+}+\mathrm{Al}^{3+}$ & $8.60 \pm 0.33^{*}$ & $+46 \% *$ \\
\hline $\mathrm{Fe}^{2+}+\mathrm{Al}^{3+}+\mathrm{Si}^{4+}$ & $3.20 \pm 0.40^{* *}$ & $-63 \% * *$ \\
\hline $\mathrm{Fe}^{2+}+\mathrm{Al}^{3+}+\mathrm{Na}_{2} \mathrm{~S}$ & $4.2 \pm 0.57^{* *}$ & $-50 \% * *$ \\
\hline
\end{tabular}

Values are expressed in nmol MDA/mg proteins, as means \pm SEM of 10 determinations $\mathrm{Si}^{4+}-0.54 \mathrm{mmol} / \mathrm{l} \mathrm{Na} \mathrm{SiO}_{3} ; \mathrm{Na}_{2} \mathrm{~S}-90 \mu \mathrm{mol} / \mathrm{l} \mathrm{Na}{ }_{2} \mathrm{~S} \cdot 9 \mathrm{H}_{2} \mathrm{O} ; \mathrm{Al}^{3+}-3.5 \mu \mathrm{mol} / / \mathrm{AlCl}_{3} \cdot 6 \mathrm{H}_{2} \mathrm{O}$ *significant changes vs. samples with iron ions without other minerals $(p<0.001)$

**significant changes vs. samples with iron and aluminium ions $(p<0.001)$

\section{Discussion}

In this paper, we present in vitro effects of some minerals on lipid peroxidation processes activated by iron ions with/without ascorbate.

Several studies have reported the relationships between Alzheimer's disease and concentrations of aluminium, silicon and iron ions in the brain. Elevated levels of silicon ions in the diet can reduce the deposition of aluminium in the amyloid plaques characteristic for Alzheimer's disease (Bocca et al., 2005; GilletteGuyonnet et al., 2007). On the other hand, crystalline silicon dioxide also induced formation of oxygen radical species in cultured rat alveolar macrophages and subsequently initiated caspase activation and triggered the apoptosis (Shen et al., 2001). In several studies, the high incidence of Alzheimer's dementia was found correlating with increased levels of $\mathrm{Al}^{3+}$ in drinkable water (Rondeau et al., 2000; Flaten, 2001).

In our experimental conditions, the addition of $\mathrm{Si}^{4+}$ ions reduced the intensity of $\mathrm{LP}$, activated either by $\mathrm{Fe}^{2+}$ or $\mathrm{Fe}^{2+}+$ ascorbate, in rat brain homogenates (Table 1).These findings are consistent with the paper describing about the possible use of silicon ions as therapeutic agents for Alzheimer's disease (Gillette-Guyonnet et al., 2007). 
However, we observed significant inhibitory effect of sodium sulphide on intensity of MDA-TBA production in the presence of iron ions. The $\mathrm{Fe}^{2+}$ ions alone acted as activators of LP processes. Their activation effect is increased by the high temperature and the addition of ascorbate which maintains iron in the form of divalent ions - necessary for the Fenton's reaction. We explain sulphide interference in these processes by the production of its insoluble complexes with iron ions (FeS). In this way, the sulphide may contribute to declining levels of iron ions needed for the activation of LP. This intervention of the sulphide was not sufficient if the mixture of iron with ascorbate was used for activation of LP. Probably, the concentration of $\mathrm{Fe}^{2+}$ is higher than the capacity of FeS production and the remaining part of the iron ions is maintained by ascorbate in the form of $\mathrm{Fe}^{2+}$ - required for LP processes. Our results are supported by the work of Schreier et al. (2010) who described hydrogensulphide as a neuroprotective factor in the brain. Mutual combination of $\mathrm{Si}^{4+}$ ions and sulphide (Table 2) decreased the iron-activated LP to the similar value as $\mathrm{Si}^{4+}$ did alone but $\mathrm{Na}_{2} \mathrm{~S}$, used separately, inhibited LP more efficiently (Table 1).

On the other hand, we found the activation effect of aluminium ions on the $\mathrm{LP}$ intensity in the presence of $\mathrm{Fe}^{2+}$. We assume the impact of $\mathrm{Al}^{3+}$ on active or regulatory centres of some antioxidant enzymes (superoxiddismutase, catalase, gluthationperoxidase) could result in the reduction of their antioxidant functions. Subsequently, the imbalance between prooxidant and antioxidant mechanisms in cells may cause the predominance of reactive oxygen species (ROS) production. The decreased activity of antioxidant enzymes after $\mathrm{AlCl}_{3}$ exposure through a diet was found in the rat brain by Nehru and Anand (2005). These authors also presented a correlation between the accumulation of $\mathrm{Al}^{3+}$ in the brain and the brain oxidative damage. Primary effects of aluminium on cerebral functions were explained via damage of cell membranes. Lipid peroxidation of biological membranes resulted in the loss of membrane fluidity, changes in membrane potential, increase in the membrane permeability and alterations in receptor functions. Metals without redox capacity, e.g. $\mathrm{Al}^{3+}$ and $\mathrm{Be}^{2+}$, could increase ferrousinduced LP by changes in the availability of fatty acids for free-radical attacks or by facilitation of the propagation of LP (Oteiza et al., 1993). Aluminium is known to be bound to the $\mathrm{Fe}^{3+}$-carrying protein, transferrin, what can cause the decrease in its binding of $\mathrm{Fe}^{3+}$. This free iron ion can be subsequently reduced by endogenous (or added) ascorbate to $\mathrm{Fe}^{2+}$, which activates LP. The increase in free intracellular $\mathrm{Fe}^{2+}$ causes the peroxidation of membrane lipids and in this way it can lead to membrane damage. The addition of $\mathrm{Si}^{4+}$ ions or sodium sulphide to samples with aluminium decreased the iron-activated LP, but had also the protective effect against $\mathrm{Al}^{3+} / \mathrm{Fe}^{2+}$-activated LP.We suppose that the negative effect of aluminium may be suppressed by the presence of some antioxidant or protective compounds in the diet (e.g. silicon ions or sodium sulphide). The protection against aluminium effect in the body might be enabled e.g. by: 
- the inhibition of oral absorption of aluminium ions in the gastrointestinal tract,

- the formation of aluminium-silicon complexes, and thereby reducing the bioavailability of aluminium for its deposition into amyloid plaques,

- the increase in renal excretion of aluminium.

\section{Conclusion}

The present study indicates that exposure of the brain tissue to aluminium ions, in the presence of iron ions and higher temperature, leads to the activation of lipid peroxidation - one of the biochemical processes responsible for neuronal dysfunction. The effect of aluminium is decreased in the presence of silicon ions or sodium sulphide. However, the question remains, how a long-term intake of trace elements in the diet (e.g. in mineral water) could lead to the imbalance between the prooxidants and antioxidants in the body? Similarly, can a high consumption of aluminium in the diet cause its accumulation in the brain and increase the formation of amyloid plaques observed in Alzheimer's disease?

It was published, that intake of silicon ions (10 mg/day) from drinking water was associated with a reduced risk of dementia (Rondeau et al., 2000). In fact, we assume that the optimal ratio of silicon and aluminium ions can exert positive effect on brain functions in vitro conditions. The mineral water from Trenčianske Teplice, monitored in our previous work, contains these ingredients in the ratio 1:150 (Al:Si) (Durfinová et al., 2010). However, we assume that also the high $\mathrm{H}_{2} \mathrm{~S}$ content could be favourable for the inhibition of activated LP by the mineral water. This impact may be realized via chelating of iron ions, which are necessary for the lipid peroxidation.

Acknowledgements: The authors thank to M. Čičmancová and K. Karaindrosová for technical assistance.

\section{References}

Bocca, B., Forte, G., Petrucci, F., Pino, A., Marchione, F., Bomboi, G., Senofonte, O., Giubilei, F., Alimonti, A. (2005) Monitoring of chemical elements and oxidative damage in patients by Alzheimer's disease. Ann. Ist. Super. Sanita 41(2), 197-203.

Carlise, E. M., Curran, M. J. (1987) Effect of dietary silicon and aluminium on silicon and aluminium levels in rat brain. Alzheimer Dis. Assoc. Disord. 1, 83-89.

Donald, J. M., Golub, M. S., Gershwin, M. E., Keen, C. L. (1989) Neurobehavioral effects in offspring of mice given excess aluminium in diet during gestation and lactation. Neurotoxicol. Teratol. 11, 345-351.

Ďurfinová, M., Brechtlová, M., Kuračka, L'., Zálešáková, J., Čelko, J., Liška, B. (2010) Effect of mineral water from Trenčianske Teplice (drinkable source, drill SB-3) on lipid peroxidation in vitro. Prague Med. Rep. 111(4), 257-262.

Exlay, C. (1999) A molecular mechanism of aluminium-induced Alzheimer's disease? J. Inorg. Biochem. 76(2), 133-140.

Flaten, T. P. (2001) Aluminium as a risk factor in Alzheimer's disease, with emphasis on drinking water. Brain Res. Bull. 55(2), 187-196. 
188) Prague Medical Report / Vol. 113 (2012) No. 3, p. 181-188

Forbes, W. F., Agwani, N. (1994) A suggested mechanism for aluminium biotoxicity. J. Theor. Biol. 171(2), 207-214.

Gillette-Guyonnet, S., Andrieu, S., Vellas, B. (2007) The potential influence of silica present in drinking water on Alzheimer's disease and associated disorders. J. Nutr. Health Aging 11(2), 119-124.

Halliwell, B., Gutteridge, J. M. C. (1999) Free Radicals in Biology and Medicine, $3^{\text {rd }}$ Edition. Oxford University Press, Oxford.

Lowry, O. H., Rosebrough, N. J., Farr, A. L., Randall, R. J. (1951) Protein measurement with folin phenol reagent. J. Biol. Chem. 193, 256-272.

Nehru, B., Anand, P. (2005) Oxidative damage following chronic aluminium exposure in adult and pup rat brains. J. Trace Elem. Med. Biol. 19, 203-208.

Ohkawa, H., Ohishi, N., Yogi, K. (1979) Assay for lipid peroxides in animal tissues by thiobarbituric acid reaction. Anal. Biochem. 95, 351-358.

Oteiza, P. I., Fraga, C. G., Keen, C. L. (1993) Aluminium has both oxidant and antioxidant effects in mouse brain membranes. Arch. Biochem. Biophys. 300(1), 517-521.

Rondeau, V., Commenges, D., Jacqmin-Gadda, H., Dartigues, J. F. (2000) Relations between aluminium concentrations in drinking water and Alzheimer's disease: an 8-year follow-up study. Am. J. Epidemiol. 152(1), 59-66.

Schreier, S. M., Muellner, M. K., Steinkellner, H., Hermann, M., Esterbauer, H., Exner, M., Gmeiner, B. M., Kapiotis, S., Laggner, H. (2010) Hydrogen sulfide scavenges the cytotoxic lipid oxidation product 4-HNE. Neurotox. Res. 17(3), 249-256.

Shen, H. M., Zhang, Z., Zhang, Q. F., Ong, C. N. (2001) Reactive oxygen species and caspase activation mediate silica-induced apoptosis in alveolar macrophages. Am. J. Physiol. Lung Cell. Mol. Physiol. 280(1), 10-17.

Zálešáková, J., Čársky, J. (2005) Silicon in natural mineral waters, its biological role and possibility of medical use. Rehabilitacia 42(2), 67-72.

Ďurfinová M.; Brechtlová M.; Kuračka L'.; Zálešáková J.; Čelko J.; Liška B. 